\title{
REGIONAL DYNAMICS AND PROSPECTS FOR PEACE IN THE CONTEXT OF PAKISTAN-RUSSIA COOPERATION
}

\author{
Fazal Rabbi \\ Associate Professor, Department of Pakistan Studies, \\ National University of Modern Languages, Islamabad. \\ frabbi@numl.edu.pk \\ Javed Ali Kalhoro \\ Assistant Professor, Department of Pakistan Studies, and Manager Executive Development Centre \\ National University of Modern Languages, Islamabad. \\ drjavedali@numl.edu.pk \\ Muhammad Shakeel Ahmed \\ Assistant Professor, Centre for Policy and Studies, COMSATS University, Islamabad. \\ shakeel.ahmed@comsats.edu.pk
}

\begin{abstract}
The bilateral relationship between Pakistan and Russia since 1947 has experienced many ups and downs. Several factors that directly or indirectly influence the nature and direction of bilateral relations between these two countries are the United States, India, and Afghanistan, etc. After many years of stagnation, there have been clear positive prospects for the development of bilateral and multilateral relations between Pakistan and Russia since September 11, 2001. Pakistan's decision of joining the war against terror and efforts for peace and stability in the region has substantially changed Russian's perceptions of Pakistan's role. The CPEC and Russian's growing interest in trade and investment relations with Pakistan also provide opportunities for close interaction between these two countries. In the new international setup, the platform of SCO has provided an opportunity for improving the bilateral relations between Pakistan and Russia on certain issues of common interests including trade cooperation, countering terrorism, drug trafficking, and regional stability, etc. In the post-9/11, the bilateral relations- cooperation in various fields of mutual interest between Pakistan and Russia have been examined in this article.
\end{abstract}

Keywords: Pakistan, Russia, Bilateral Cooperation, CPEC, Regional Peace

\section{INTRODUCTION}

The collapse of the Union of Soviet Socialist Republic (USSR) and the international sanctions against Russia due to its involvement in the southeast of Ukraine have largely limited the possibilities of its successful foreign policy in Western Europe. In such a situation it is quite apparent that Russia should act more actively in southern directions; in addition to the South Caucasus, the regions of South and South-West Asia. Russia has long mutually beneficial, multi-faceted contacts with the region of South and South-West Asia, and today the states of these regions have no acute political and territorial problems. However, due to various circumstances, the socio-economic and political situation in the region of South Asia is not stable; the possibility of conflict here is quite high. From the socioeconomic and political perspective of these regions, the security of Russia's southern borders depends. It is in Russia's interest to develop cooperation with all countries of these regions both in bilateral and multilateral formats (Secrieru, 2015). Amongst these countries, Pakistan's geo-strategic importance cannot be ignored.

Pakistan is at the junction of important geopolitical regions - South-West and Central Asia, a powerful army with nuclear weapons, is the world's second-largest Muslim state in the world and has a rapidly growing economy. The withdrawal of the International Security Assistance Force in Afghanistan has immeasurably increased Pakistan's role in ensuring the security of South and Central Asia. One such state, Russia should be interested in building good-neighborly relations with Pakistan, 
which, undoubtedly, plays an important role in ensuring security on its southern borders. Pakistan's deteriorated relationship with the US, more close interaction with China along with the launching of the China Pakistan Economic Corridor, and its membership in the Shanghai Cooperation Organization are providing new opportunities for growing relations with Russia.

This article has revealed the process of developing bilateral ties between Pakistan and Russia post 9/11 and has clarified the main areas of bilateral cooperation. The causes of the slow growth of their relations and current promising areas for cooperation have been identified.

\section{Historical Timeline}

The diplomatic relations between Pakistan and the USSR were established on May 1, 1948. Even though, historically both countries did not have any controversial issues, however, the relationship between these two countries did not develop easily. Several factors have influenced the development of relations between the two countries. One of these factors was US policy in the region of South Asia. Soon after independence in 1947, the United States involved Pakistan in the cold war by signing several security-military agreements with Pakistan including SEATO, CENTO, and Pakistan became the most allied ally of the US in Asia on the southern borders of the USSR (Hanif, 2013). By joining SEATO, Pakistan became an ally to the America's Cold War against Communism. This strategic conglomerate strengthened a non-democratic force within Pakistan, eroding the existing fragile democratic setup in the country, and formed a sort of "constitutional dictatorship" that was used as a strong tool make Pakistan's membership in SEATO, intact. The pact was a logical zenith of TrumanAcheson containment that called for robust alliance system, directed by the U.S. and inclusive security pacts.

The next factor that had and still has an impact on the Pak-Russia relations is the close interaction of the USSR with India. According to Rasul B. Rais Pakistan was frequently told that "the road to Moscow was via New Delhi" (Rais, 1991). The geopolitical interests of Russia and India reduce the possibility of expanding cooperation between Moscow and Islamabad. In the interest of maintaining and strengthening relations with India, the USSR for a long time restrained the development of its relations with Pakistan.

\section{Civil War in Afghanistan}

Another major factor that influenced the development of relations between the USSR and Pakistan was the civil war in Afghanistan in the 1980s, which kept the USSR and Pakistan poles apart. Historically, Pakistan's relations with the Soviet Union, and then with Russia (as its successor), were turbulent, marked by downturns and ups. Mutual distrust and tension that existed in the relations of the two states in the past were due to the existing bi-polarity of the world and the general alignment of forces in the international arena, connected with the military-political confrontation between the two socio-economic blocs, the capitalist and the communist (Khan, 2014).

After the withdrawal of Soviet troops from Afghanistan in 1989 and the collapse of the USSR in 1991, there were more favorable prerequisites for improving the bilateral relationship between Pakistan and Russia. Since then, there were visible positive signs in the new Russian foreign policy towards the region of South Asia. Russia has been gradually drifting away from its traditional policy of supporting India on certain international issues including Kashmir. The Russian government concentrated its foreign policy objectives on trade and economic relations and was searching for a favorable trade market. Pakistan was also looking for opportunities of strengthening its relations with Russia in the post-Cold War period (Azizian \& Vasilieff, 2003). It was during this time that the political dialogue between Pakistan and Russia gradually gained momentum.

The diplomatic initiatives between Pakistan and Russian in the 1990s include the visits to Russia by Pakistan; Foreign Secretary Akram Zaki, in 1992, and Foreign Minister Sardar Asif Ahmed Ali in July 1994. In return, Russian officials visited Pakistan i.e., Vice President Alexander Rutskoy in December 1992, the first Foreign Minister A.V. Kozyrev in April 1993, the first deputy Foreign Minister Adamishin in May 2004, and Russian parliamentary delegation visit to Pakistan in September 1995.

During these visits, several documents on trade, economic, scientific, technical, and cultural cooperation between the two countries were signed. The signing of these and other similar agreements in the years that followed seemed to revive bilateral contacts, but the stereotyped approaches of mistrust and suspicion towards each other during the years of the Cold War prevented countries from initiating active cooperation. The official visit of Pakistani Prime Minister Nawaz Sharif to Moscow 
in April 1999 and the signing of an agreement on trade and economic cooperation also facilitated the opening of active bilateral relations between these two countries. However, it was since the 9/11 events that the bilateral relationship between Pakistan and Russian extensively improved.

\section{DISCUSSION}

After the terrorist attacks in the United States on September 11, 2001, Pakistan found itself at the epicenter of the global fight against international terrorism. Under the pressure of the United States and other countries, Pakistan joined the anti-terrorist operation in Afghanistan. Since that time, Russian-Pakistani relations have entered a period of dynamic development. In January and March 2002, additional secretaries of the ministry of foreign affairs of Pakistan, Aziz Khan and Aneesuddin visited Russia for economic and political consultation. In the same year, special envoys Najmuddin Shaikh and Asfandyar Wali also visited Russia for improving bilateral ties. From the Russian side Chairman of the Russian Foreign Relations Committee Dmitriy O. Rogozin visited Pakistan in April 2002 and Deputy Foreign Minister Antoly Safonov, visited Pakistan in May, the same year.

Russia was more interested in Pakistan because of its trade and economic relations with Pakistan. Subsequently, the parliamentary delegation of Russia consisted of six members who visited Pakistan in May 2002 and expressed their interests in investment in Pakistan, primarily in the field of construction, agriculture, and heavy machinery. Consequently, Pakistan-Russia Business Council and Forum were created (GoP, 2003). Thus trade relations between Pakistan and Russia improved and the volume of trade kept fluctuating between " $\$ 63$ million in 1998-1999, \$93.34 million in 1999-2000, $\$ 69.64$ million in 2000-2001, \$83.45 million in 2001- 2002, \$60.47 million in 2002-2003 and \$154.53 million in 2003-2004" (Khan \& Amin, 2012).

\section{Musharaf's Regional Plan}

In February 2003, President Musharraf paid an official visit to Moscow, where four agreements were signed, including i) MoU on Cooperation between the Ministry of Foreign Affairs of Pakistan and Russia, ii) Culture program for 2003-2006 iii) MoU on Cooperation between the Diplomatic Academies and vi) MoU on Expansion of Karachi Steel Mill. These agreements allowed laying the groundwork for building up Russian-Pakistani interaction in bilateral and multilateral forums, which allowed the relations of the two countries to be withdrawn from the state of stagnation, raising them to a new level of realistic approach in their relationships (GoP, 2004).

The most important project of bilateral cooperation was the modernization of the metallurgical plant-Karachi Steel Mill, built in Pakistan with the help of the USSR - in practice, it has not moved from a dead center. A Memorandum of Understanding was signed in which both sides expressed their intention to increase (with the help of Russia), the plant's productivity initially to 1.5 million. Let us emphasize that the Karachi Steel Mill, is still the main result of Soviet-Pakistani economic cooperation. It was put into operation in 1985 and produced 1.1 million tons of steel a year, which drastically reduced the dependence of Pakistan at that time on metal imports, and also reduced the foreign exchange costs. During the visit, agreements on cooperation in science, culture, and education were also signed, but even these were only partially implemented, mainly in the sphere of culture (Hanif, 2013).

It is significant that on the day of the arrival of the President of Pakistan to Moscow, Russian President Putin called on his initiative to the then Prime Minister of India, Vajpayee, and assured him that negotiations with the Pakistani leader would not affect the close nature of their relations with India. Musharraf understood the position of the Russian side and during his visit to Putin did not raise the issue of military-technical cooperation, realizing that this is simply pointless. He was well aware that Russia would never give up billions of military contracts with India, which could be thwarted if similar ties were established with Pakistan.

At the time there was a rapprochement between Russia and Pakistan on selected regional and global problems, including the fight against international terrorism and religious extremism, illegal trafficking in nuclear materials and drugs, prevention of an arms race in outer space, and transnational organized crime. In addition, the leading areas of promising mutually beneficial cooperation were identified: energy, oil and gas production, metallurgy, use of space technologies, and telecommunications, etc. (Donalson, 2014).

Musharraf's visit was followed by a series of ministerial visits which took place to the strengthened bilateral relationship between Pakistan and Russia. From Pakistani side: Yar Mohammad 
(18 ${ }^{\text {th }}$ July 2003), Awais Ahmad (21-25 July 2003), Liaquat Ali Jaoti (23-26 September 2003), Amir Hussain, speaker of National Assembly (October 2003); while from the Russian side: Igor Ivanv (June 2003), Sergey Stepashin (December 2003), Anatoly Safonov (23-6 February 2004) (Foreign Office, 2003-04).

The political contact between Pakistan and Russia further developed at the highest levels in 2005, both countries' Presidents met at UN General Assembly and, during Shanghai Cooperation Organization (SCO). On June 15, 2006, President Musharraf met with President Putin, in Shanghai, while on September 15, 2006, Prime Minister Shaukat Aziz met with Russian Premier Mikhail Fradkov, in Dushanbe. Intensive dialogues at the foreign minister's level were held and interministerial consultation was initiated. In November 2006, the foreign minister of Russia Sergey Lavrov visited Pakistan, met with Foreign Minister Khurshid Kasuri, and exchanged extensive and productive talks on counter-terrorism, strategic stability, international security, and bilateral cooperation in various fields (Owais, 2007).

\section{Russia's Regional Plan}

In April 2007, the Russian Prime Minister, M.E. Fradkov paid an official visit to Pakistan. During the visit, three memorandums of understanding were signed. The Parties extended the Agreement of 1997 on cooperation in the fight against the illicit traffic and abuse of narcotic drugs and psychotropic substances. Nevertheless, in the practical field, during the three days, the official visit of the Russian Prime Minister little has been done. But this was the first visit of such a high level after almost four decades of oblivion. He was given the most cordial reception since the last time such a visit took place when Prime Minister A.N. Kosygin visited Islamabad in 1968-69. On $11^{\text {th }}$ June 2007, the Russian Ambassador to Pakistan stated: "Our Country pursues a dynamic foreign policy and the RussianPakistani relations occupy a special place among its priorities...our country is interested in participation in technical re-equipment, moderation and development of the Soviet production and technological base broadly presented in Pakistan and construction of new industrial projects. Russia is capable to deliver a complete set of equipment, modern industrial technologies and render technical assistance at a competitive price and a proper quality." (Business Recorder, 2007).

Russian initiative in the NATO summit in Bucharest (April 2008), about the provision of air transit routes for the delivery of non-military cargoes to the contingent of the coalition forces of the NATO military bloc deployed in Afghanistan, also negatively affected the possibilities for real cooperation between Russia and Pakistan. This transit became an alternative to the acting, by no means, insecure Pakistani transport corridor. Islamabad reacted sharply to this Russian initiative because it affected Pakistan's economic interests most sensitively (Dawn, 2008). In 2009 (from June 14-15), President Musharraf visited Russia again. In the same year in 2008-09, the volume of bilateral trade between Pakistan and Russia was $\$ 444.43$ million. Russian assistance to dislocated persons through UNHCR was \$1 million (GoP, 2009).

To a certain extent, the breakthrough in bilateral relations was the annual 4-sided summits (Afghanistan, Pakistan, Russia, Tajikistan), within the framework of which the meetings of the presidents of Russia and Pakistan were held. Initially (in Tajikistan, 2009), the expansion of bilateral cooperation was reflected in the establishment of a more trusting relationship at the highest level and the signing of several memorandums of understanding. Already at that time, in Dushanbe, within the framework of the bilateral meeting of the presidents of Russia and Pakistan, the opportunities for joint struggle against drug trafficking (including active participation in this process and Afghanistan), terrorism and extremism, participation of Gazprom in Pakistan energy projects, trade, the creation of a favorable investment climate, and some other issues came under discussion. This was already the concrete beginning of the expansion of bilateral relations.

On August 18, 2010, in Sochi, in the framework of the quadripartite summit with the participation of the heads of Russia, Afghanistan, Pakistan, and Tajikistan, a meeting was held between the Presidents of Russia and Pakistan, during which the possibilities of cooperation in the financial sphere, the opening of Pakistani banks branches in Russia and Russian banks branches in Pakistan and the reception of Pakistani students for training in Russia, etc. were discussed (Abbas, 2016).

The Pakistan-Russia Inter-Governmental Commission (IGC), on trade, economic, scientific, technical, and cultural cooperation began its practical activities, which indicated that at that time both sides attached considerable importance to the development of bilateral relations. The first meeting 
IGC on Trade, Economic, Scientific, Technology and Cultural Cooperation, was held in September 2010. The meeting was presented by Pakistani State Minister of Foreign Affairs Hina Rabbani Khar and Russian Minister of Sport, Tourism and Youth Policy, VL. Mutko. In September 2012, another meeting was held in Islamabad; where the Russian co-chairman in the Commission VL. Mutko met then not only with the Minister of Foreign Affairs of Pakistan but also with President Zardari. However, in the commission meeting of 2010, it was decided to proceed to a concrete discussion of cooperation in the field of energy (GoP, 2003).

\section{Pak-Russia as Regional Players}

In 2011, while his meeting with Pakistan's Prime minister Yousaf Raza Gillani, Putin publicly admitted that Pakistan-Russia is extremely important with regards to the promotion of regional peace and stability. Putin also endorsed Pakistan to join SCO, and Russia also offered its assistance to Pakistan in the expansion of Steel Mill, Muzaffargarh, and Guddu power plants, and interest was also shown in the Thar Coal Project. The NATO strikes on the Salala check post were also condemned by the Foreign Minister of Russia and called it a violation of the sovereignty of Pakistan (Hanif, 2013).

During the official visit of President Zardari to Moscow (May 11 - 14, 2011) a Memorandum of Understanding and cooperation in the field of energy was signed, which included cooperation in the field of geological exploration for oil and gas, assistance in the development of these energy resources and their extraction, in the production of coking coal, and the development of the energy infrastructure as a whole (The News, 2011).

This period was marked by the intensification of foreign political contacts between the two countries in various organizations i.e., Organization of the Islamic Conference and the SCO. All this had a positive impact on bilateral cooperation. From 2010 to 2013, the President of Pakistan Zardari met with the Russian president six times - in the framework of meetings of the heads of states. Other senior officials' visits during 2012-2013 include Hina Raabi Khar in February 2012, Chief of Army Staff in October 2012, Air Chief Marshal in 2012, Foreign Secretary in August 2013 and from Russian side; Foreign Minister in 2012 and Chairperson of Russian Federal Council in February 2013. Bilateral trade during 2010-2013 significantly increased, from \$135.904 million to \$152.162 million (MoFA, 2003).

In 2012, the foreign minister of Pakistan, Hina Raabi Khar met with the foreign minister of Russia Sergey V. Lavrov in Moscow. The meeting discussed the prospects for cooperation in energy, metallurgy, the issues of the Afghan settlement, the joint struggle against terrorism, the situation in the Arab world, and the prospects for Iran's nuclear program. In early October 2012, S.V. Lavrov paid a return visit to Islamabad, during which three Memoranda were signed i.e., Mutual understanding in the field of- metallurgy, power engineering, and railway transport. But, despite the apparent intensity of contacts and ties between Pakistan and Russia at the highest level, a decline began in political, trade-economic, scientific-technical, and cultural relations. The refusal of President Putin to come to Islamabad for the summit which was to be held in October 2012, between Afghanistan, Pakistan, Russia, and Tajikistan, has been shocking news for Pakistan. As Russia was one of the main negotiators at this meeting, thus the event was canceled. Such a decision by Moscow was completely unexpected and was taken with great annoyance by Pakistan. There are different opinions as to why the Russian President refused to go to the meeting. One of the main reasons experts connect with previous negotiations with representatives of Gazprom (a large Russian Company) on the latter's participation in the construction of a gas pipeline from Iran to Pakistan and then to India. Russia hoped to get more rights to participate in this project than Pakistan was ready to provide (Hanif, 2013).

It is also extremely important for Russia to cooperate with Pakistan in the fight against Afghan drug trafficking. Since, Russia has been actively participating in the program of the RussiaNATO Council for the training of personnel for the specialized units of Afghanistan, Pakistan, and the countries of Central Asia. During this period, dozens of Pakistanis were trained in Russia. Anti-drug cooperation is also developing in a bilateral format - based on the agreement signed in 2010 between the Federal Drug Control Service of Russia and the Ministry of Drug Control of Pakistan (GoP, 2002).

The cooperation in the scientific, technological and trade were strengthening, and Russian continues to support the work of Multan hydropower plants and a metallurgical plant in Karachi. The Russian firms have also been also actively involved in the construction of high-voltage transmission 
lines in Pakistan, the creation of a hydropower complex in Gazi Barotha, and the construction of the Munda dam, etc.

In May 2011, during a meeting with President Zardari at the Kremlin, the Russian President Dmitry Medvedev said: "We are interested in coordinating our efforts on the international arena. It is obvious that our countries are facing absolutely the same threat, I mean international terrorism ... we have to do everything so that we could jointly counter the main evil of the $1^{\text {st }}$ century." (The News, 2011).

However, according to some Russian experts, the main enemy of the international community in Afghanistan and Pakistan is not so much terrorism but only drugs. While caparisoning the human death in the war on terror, the Director of the Russian Federal Drug Control Service, Viktor Lvanov, said: "Afghan heroin has killed more than one million people in Eurasia, including at least half a million Russian citizens." (Galeotti, 2015).

It is not surprising that in the course of 4 summits in Dushanbe in early September 2011, the issues of fighting terrorism and extremism, drug trafficking, implementation of energy projects were at the center of attention of the heads of state of Afghanistan, Pakistan, Russia, and Tajikistan. The presidents of these countries completely agreed with the statement of the Russian President Dmitry Medvedev, who stated: "I believe all of my colleagues are united on one issue: the responsibility of what is happening in our region will in the final account inevitably rest with our countries-Russia, Tajikistan, Afghanistan, and Pakistan." (Dyomkin, 2011).

On May 1, 2013, Russian Consul General Andrey V. Demdov stated: "The history of our bilateral relations saw both good and not so good. But irrespective of the state of the relations, both countries always felt the necessity to maintain good contacts." (Abbas, 2016).

Along with bilateral visits and dialogue between the civil, military, and economic institutions of Pakistan and Russia, various multilateral forums played an important role in strengthening bilateral ties, i.e., Inter-Government Commission (IGC), Joint Working Group (JWG), Joint Consultation Group on Strategic Stability, Joint Strategic dialogues, Informal Dialogue on Afghanistan and Dushanbe Four, etc.

There is no doubt that after the withdrawal of NATO-led ISAF including US troops from Afghanistan in 2014, the situation inside this country become even more acute. The withdrawal of troops from Afghanistan began under difficult conditions, leaves a lot of unresolved problems, including the end of terrorism in Afghanistan and the region. The Taliban and its allies continue to pose a serious threat to the peace and security of the region. Universal corruption, drug trafficking, the tyranny of warlords (field commanders), organized crime, unemployment - all these remain an integral part of today's Afghanistan. Though on several occasions the Russian government supported the project of power transmission from Tajikistan and Kyrgyzstan through Afghanistan to Pakistan (with possible continuation to India) - CASA-1000, and also expressed its support for the idea of constructing a TAPI gas pipeline from Turkmenistan to Afghanistan, Pakistan, and India. However, to date, the implementation of these two projects is hardly possible. The extremely difficult internal political situation in Afghanistan does not allow the construction and further operation of ground power facilities, such as transmission lines and pipelines (Hanif, 2013).

The domestic political situation in Afghanistan is one of the dominant reasons, calling for closer cooperation between Russia and Pakistan. An increase in the level of Russian-Pakistani relations will unequivocally help reduce the internal political tension in Afghanistan. After the withdrawal of NATO troops from Afghanistan in 2014, there only remains some contingent of US troops, who, just like before, needs supplies of food, fuel, and other goods, and they go to Afghanistan on already worked out routes, i.e. through Pakistan and Russia (Dawn, 2007). Stephen Blank stated: "Pakistan and Russia have covertly developed geopolitical and strategic relations that in the wake of withdrawal of NATO-led ISAF and US forces by 2014, Pakistan will be a crucial player in Afghanistan and hence speeded up the advancement of relations with this country." (Blank, 2012). In this case, the coordination of the actions of Islamabad and Moscow can positively affect this process and can have an impact on improving the domestic political situation in Afghanistan and can reduce the volume of drug trafficking from Afghanistan to Russia. It is for this reason that the improvement of Pakistan-Russian relations can have a positive impact on the situation in Afghanistan.

The current status of Pak-Russia relations is characterized by mutual bilateral trust, and convergence of interests on regional and international issues, including counter-terrorism and drug 
trafficking, regional stability, energy, education, cultural ties, and the most important bilateral trade ties. Russia is helping Pakistan to overcome the energy crisis; the installation of LPG Air Mix plants, LNG 1.7 billion projects, $600 \mathrm{MW}$ combined cycle power plant, and the implementation of NorthSouth Gas Pipeline agreement signed in October 2015.

Defence ties were also strengthened between Pakistan and Russia with the visit of ColonelGeneral Vladimir Chirkin to Pakistan in 2013 and General Raheel Sharif to Moscow in June 2015. Russia lifted an arms embargo on Pakistan in 2014, and in November both countries signed a defence cooperation agreement. In September-October 2016, joint military exercise "Friendship 2016", took place, the first-ever development in their relations. A Russian Navy submarine "Severmorsk" also arrived in Pakistan and participated in the international naval exercise in February 2017.

In the current regional and international scenario China-Pakistan Economic Corridor (CPEC) and the platform of the Shanghai Cooperation Organization (SCO) offer new opportunities for both Pakistan and Russia to improve and enchase their bilateral relations. The Russian leadership is aware of the geo-strategic location of Pakistan, and the role Pakistan can play in the promotion of regional integration, peace, and prosperity at the global level. Thus Moscow shows its interest to get benefits from its access to the Arabian Sea, through Gwadar port, that CPEC provides, and to link it with EEU (Eurasian Economic Union). It has extended its support to Pakistan's membership in SCO. In the SCO Summit on June 8-9, 2017, at Astana, the members' countries Russia, China, Kazakhstan, Tajikistan, Uzbekistan, Tajikistan, and Kyrgyzstan agreed to provide membership to Pakistan in SCO. (The Diplomat, 2017). The President of Russia V. Putin stated: "the accession of India and Pakistan would increase the organization's relevance, both in the region and worldwide." (Rai, 2014).

On June 24, 2016, the Memorandum of Obligations was signed by Sartaj Aziz, advisor on foreign affairs at SCO's Heads of State Summit in Tashkent, whereas the President of Pakistan, Mamnoon Hussian led the delegation at the signing ceremony. Thus, Pakistan becomes the full member of SCO. Since 2005, Pakistan has been remained a regular observer at SCO and applied for membership in 2010. Pakistan's membership in SCO is considered by the Ministry of Foreign Affairs of Pakistan as "a significant landmark on our foreign policy front" (MoFA, 2016). At the $16^{\text {th }}$ meeting of the SCO Heads of the States in Sochi (30 November-1 December 2017), the Prime Minister of Pakistani Shahid Khaqan Abbasi and Russian Primer Dmitry Medvedev, along with other members countries confirmed their outstanding support of "China's One Belt and One Road Initiative" and agreed on coordination of international, regional and national projects (SCO, 2021). Thus, apart from China Pakistan Economic Corridor, the platform of SCO is providing everlasting opportunities for both Pakistan and Russia to improve and enhance its approaches in the new regional and international setup and that it would have positive impacts on both countries bilateral ties.

\section{CONCLUSION}

An analysis of the growing relationship between Pakistan and Russia in the post 9-11, showed that both states made efforts at a high level to maintain and develop bilateral relations in various fields. Nevertheless, often concluded interstate agreements and plans were not implemented in practice due to various factors i.e., Pakistan's alliances with the US in the war against terrorism in Afghanistan and the transfer of the Russian economy to market relations, the Russian often puts economic interest at the center of the matter at the expense of political relations while dealing with foreign countries including Pakistan. However, the situation in the world and particularly in the regions of South, South-West, and Central Asia is changing rapidly. The Indian factor is also losing its relevance in Pakistan-Russian relations. The rapidly developing India in its foreign policy no longer focuses exclusively on Russia, it implements multilateral diplomacy and increases purchases of military equipment from the United States, Israel, and France.

In the changing regional and international dynamics, Pakistan needs a comprehensive policy towards Russia to take advantage, as its relationship with the US is deteriorating while its dependency on US aid is also decreasing. For Pakistan, cooperation with Russia would be most productive in the infrastructure and the energy sectors including nuclear, communications, metallurgy, irrigation and land improvement, and combating international terrorism. It is quite obvious that Russia should not ignore the geo-strategic importance of Pakistan that it can play a dominant role in regional and international politics. Russia needs to look to the realities of today and must make adjustments to its foreign policy and strategy towards Pakistan. 
The situation in Afghanistan and possible solutions to the Afghan problem is one of the main problems. It is logical to assume that in the long-term Russia will seek to establish a closer relationship with Pakistan, which will become an even more important figure in the context of the Afghan situation. It is unlikely that any state will tolerate, for example, a situation similar to that in Afghanistan after the withdrawal of Soviet troops in 1989. As for the Afghan factor, it is quite obvious that Russian-Pakistani cooperation in the field of terrorism and combating drug trafficking would help normalize the situation both in Afghanistan and Pakistan. Trade-economic and politicalcultural, are the main area of cooperation between these two countries in the medium term. To develop a comprehensive dialogue between Pakistan and Russian, there are favorable opportunities for the long term, especially as Pakistan constantly expresses interest in mutually advantageous cooperation in the field of economy, science, military equipment, energy, culture, education, tourism, and sports. While the military-technical cooperation between Pakistan and Russian is growing in recent years and would become stronger soon.

The Russian outstanding support of China's One Belt and One Road Initiative and its interests in CPEC is considered the new arena of growing relations between Pakistan and Russia, that would lead to agreed coordination of international, regional, and national projects. In addition to the SCO objectives of boosting trade/investment cooperation between member states of South Asia and Central Asia region, it could serve as an effective forum to enhance cooperation and interaction between Pakistan and Russia. Both Pakistan and Russia are already agreed on the cooperation of mutual trust, counter-terrorism, cultural and education interaction, peace and stability of the region and, looking forward to new avenues of cooperation and regional connectivity in the near future. Thus, SCO is not only a platform for cooperation amongst members' states but will also provide opportunities for both South Asian countries Pakistan and India to overcome their differences and work together for peace, stability, and a more secure region. Thus the platform of SCO is also providing everlasting opportunities for both Pakistan and Russia to improve and enhance their approaches in the new regional and international setup and that it would have positive impacts on both countries' bilateral ties in the near future.

\section{REFERENCES}

"Pakistan, Russia agree to promote trade, investment", The News, May 13, 2011.

Azizian, Roubeen and Vasilieff, Peter. (Spring, 2003). Russia and Pakistan: The Difficult Path to Rapprochement, Asian Affairs, Vol. 30, No. 1, p. 37

Denis Dyomkin, "Russia clinches military base deal with Tajikistan", Reuters, September 3, 2011.

Donalson, Robert H. (2014). The Foreign Policy of Russia: Changing System, Enduring Interest, (M.E Sharp, 2014), 341-34. See also Roubeen Azizian and Peter Vasilieff, pp. 50-52.

Foreign Office Year Book 2012-2013. Islamabad: Ministry of Foreign Affairs, 2003, pp. 98-100.

Foreign Office Year Book 2003-2004, p. 80

Government of Pakistan, Foreign Office Year Book 2011-2012 (Islamabad: Ministry of Foreign Affairs, 2002), p. 83

Government of Pakistan, Pakistan Foreign Relations 2002 (Islamabad: Ministry of Foreign Affairs, 2003), pp. 70-71. Also see Muhammad Hanif, pp. 71.

Government of Pakistan. (2003). Foreign Office Year Book 2012-2013. Islamabad: Ministry of Foreign Affairs. pp. 98-100.

Foreign Affairs., p. 80

(2004). Foreign Office Year Book 2003-2004. Islamabad: Ministry of ..(2009). Foreign Office Year Book 2008-2009. Islamabad: Ministry of Foreign Affairs. pp. 20, 80.

Hanif, M. (Summer 2013). Pakistan-Russia Relations: Progress, Prospects, and Constraints. IPRI Journal, No. 2 pp. 65-78.

Joint Communique following the $16^{\text {th }}$ meeting of the SCO Heads of Government Council, http://eng.sectsco.org/documents/

Khan, S., \& Amin, Nor-ul. (2012, Winter). An Overview of Pak-Soviet/Russia Relations. Central Asia, No. 71, p. 14.

Mark Galeotti, Narcotics and Nationalism: Russian drug policies and Future (Washington D: Brooking Institute, 2015), p. 4. 
Rehman, M. S. (2014). Significance of Shanghai Cooperation Organization -Pakistan's Perspective. Margalla Papers, vol. xviii, issue. 1. pp. 65-84.

Secrieru, S. (2015). Russian under Sanctions: Assessing the Damage, Srcutinsing adaptation and Evasion. Warsaw: Polish Institute of International Affairs. pp. 1-85.

Rais, R. B. (April 1991). Pakistan in the Regional and Global Structure", Asian Survey, Vol. 31. p. 390.

Iqbal, A. (2007, January 1). Russia bid to replace Pakistan as supply route: War in Afghanistan. Dawn.

Owais, M. (April 2007). Pakistan-Russia Relations: Economic and Political Dimensions. Pakistan Horizon, Vol. 60, No. 2, pp. 132-135.

Iqbal, A. (April 2, 2008). Russia bid to replace Pakistan as supply route: War in Afghanistan. Dawn News.

Blank, S. (2012, June). Russia's Quiet Rapprochement with Pakistan. Eurasia Daily Monitor, Vol. 9, Issue. 107, The Jamestown Foundation.

Khan, R. A. (December 2014). Pakistan-Russia Relations and the prospects, Opinion, Vol. 2, No. 2. pp. $14-16$

Abbas, K. (February 2016). Russian's Revival: Opportunities and Limitations for Pakistan. IPRI Review.

Khurram Abbas, IPRI Review, February 4, 2016.

Press Briefing by Spokesperson on 30 June 2016, Ministry of Foreign Affairs, Government of Pakistan, http://www.mofa.gov.pk/pr-details.php?mm=MzkwNA

Hussein, S. (2017, February 25). Russia and Pakistan's Reluctant Romance. The Diplomat, http://thediplomat.com/2017/02/russia-and-pakistans-reluctant-romance/

Jabri, P. (2017, June 10). Pakistan, Russia agree to take bilateral ties to a new level, Business Recorder. http://www.brecorder.com/2017/06/10/353707/pakistan-russia-agree-to-takebilateral-ties-to-new-level/.

Rafi, A. E. (2017, June 25). India-Pakistan and the SCO platform. Pakistan Observer. 